\title{
Thorough Characterization of Brazilian New Generation of Eucalypt Clones and Grass for Pulp Production
}

\author{
Fernando José Borges Gomes, ${ }^{1}$ Jorge Luiz Colodette, ${ }^{1}$ Auphélia Burnet, ${ }^{2}$ \\ Larisse Aparecida Ribas Batalha, ${ }^{3}$ Fernando Almeida Santos, ${ }^{1}$ and Iara Fontes Demuner ${ }^{1}$ \\ ${ }^{1}$ Department of Forestry Engineering, Federal University of Viçosa, Campus Viçosa, 36570-000 Viçosa, MG, Brazil \\ ${ }^{2}$ Centre Technique du Papier, BP 251, 38044 Grenoble Cedex 9, France \\ ${ }^{3}$ Department of Chemistry, Federal University of Viçosa, Campus Viçosa, 36570-000 Viçosa, MG, Brazil \\ Correspondence should be addressed to Fernando José Borges Gomes; fernando.gomes@ufv.br
}

Received 17 October 2014; Revised 14 January 2015; Accepted 29 January 2015

Academic Editor: Timothy Martin

Copyright (C) 2015 Fernando José Borges Gomes et al. This is an open access article distributed under the Creative Commons Attribution License, which permits unrestricted use, distribution, and reproduction in any medium, provided the original work is properly cited.

\begin{abstract}
Eucalypt wood is becoming the most important raw material for the pulp industries in South America. However, due to the high wood cost in comparison to other raw material sources, nonwoody materials are also being investigated aiming at pulp production. In this way, this paper aimed at the evaluation of eighteen eucalypt clones obtained from the Brazilian Genolyptus project, regarding their potential characteristics for pulp production. Aiming at the same goal, two species of elephant grass were also evaluated as alternative raw material sources. Through the analyses of the anatomic and chemical characteristics, five eucalypt clones and one elephant grass species were indicated for pulp production and biorefinery application. The results of this study indicate the high technological quality of Eucalyptus clones evaluated and indicate that they can be used for biorefinery applications since they have the suitable characteristics. In general, the eucalypt clones are less moist and denser and contain fewer minerals and extraneous materials than the elephant grass species, which make them more attractive for utilization in deconstruction studies aiming at production of bioproducts.
\end{abstract}

\section{Introduction}

Biomass sources such as hardwood and softwood are the main raw materials for biorefinery application, since they are largely used in the pulp mills and deliver the suitable characteristics to the final products with competitive costs. In this context, eucalypt is becoming the most important raw material. The major interest in eucalypt wood comes from its relative low production cost in certain regions, for example, in South America, due mainly to high forest productivity and high pulping yield.

It is very well known that wood quality is a factor of extreme importance when the goal is the pulp production with high industrial yield, low cost, and high quality. Wood characteristics like fiber anatomy and chemical composition are expected to affect its processability, that is, ease of delignification and the quality of the pulp products $[1,2]$. Chemical structures may vary among different wood species and even among eucalypt clones. Many studies have been done in order to increase wood productivity and improve its quality aiming at the pulp production through the selection of clones with better performance and crossings between them $[3,4]$. Good results have been observed; for example, the average productivity of the Brazilian eucalypt forests increased from $24 \mathrm{~m}^{3} / \mathrm{ha} / \mathrm{yr}$ in 1980 to $41 \mathrm{~m}^{3} / \mathrm{ha} / \mathrm{yr}$ in 2010 , representing a $71 \%$ increase in productivity of planted forests in Brazil [5].

In spite of wood to be a consolidated raw material for the pulp industry and biorefinery applications, alternative sources of biomass have been investigated to wood replacement, for example, elephant grass. High productivity plants such as elephant grass (30-45 bone dry t/ha/yr) can 
potentially supply biomass of low cost to meet the current demand [6-12]. However, the quality of such raw material aiming at pulp production is not yet fully known. Elephant grass has special characteristics for the pulp production, which are the high fiber production, similar to sugar cane [13, 14 , and its chemical composition. Some works have showed a content of $40 \%, 30 \%$, and $17.7 \%$ for cellulose, hemicelluloses, and lignin, respectively [15].

Among Brazilian pulp industries, research institutes, and universities, a research project was developed, which aimed at eucalypts forest improvements for pulp production, called Brazilian Genolyptus. In this study, eighteen eucalypt clones obtained from the Brazilian Genolyptus project were investigated regarding their potential characteristics for pulp production. Aiming at the same goal, two species of elephant grass were also evaluated as alternative source for the pulp industry. Through the analysis of the anatomic and chemical characteristics, five eucalypt clones and one elephant grass species were indicated for pulp production.

\section{Materials and Methods}

2.1. Materials. For this study, 18 eucalypt clone samples in commercial cutting age were investigated provided by GENOLYTPUS project, located in Minas Gerais State, Brazil, and also two species of elephant grass (150 days old) were studied. The complete list of samples used in this study is presented in Table 1.

Five trees of each eucalypt clone, with DBH (diameter at breast height: $1.4 \mathrm{~m}$ ) and heights corresponding to the average population, were harvested, split into five $50 \mathrm{~cm}$ long bolts at $0,25,50,75$, and $100 \%$ of the tree heights, and a $100 \mathrm{~kg}$ sample of each elephant grass species was harvested at a Federal University of Viçosa experimental station. The samples were evaluated for their moisture content at the moment of harvesting according to Tappi T264 cm-07 standard procedure [16]. The eucalypt clones samples were chipped in a laboratory chipper, a Chogokukikai model, equipped with 3 knives and 2 screens ( 40 and $13 \mathrm{~mm}$ ). Both eucalypt clones and elephant grass chips were well mixed $\left(260 \mathrm{~m}^{3}\right.$ rotary mixer) and the eucalypt clones samples were screened according to SCAN-CN 40:94 procedure [17]. For eucalypt clones samples, the chips retained in the $3 \mathrm{~mm}$ and $7 \mathrm{~mm}$ screens were collected and mixed again, air dried to about $15 \%$ of moisture, and stored in large plastic bags. The elephant grass samples were manually chipped, producing wet chips about $5 \mathrm{~mm}$ long. The chip thickness was quite variable since it depended on the grass thickness, which varies from $1 \mathrm{~cm}$ diameter to $4 \mathrm{~cm}$ diameter. The grass chips were air dried to a moisture content of about $15 \%$ and stored in large plastic bags.

\subsection{Methods}

2.2.1. Biomass Density. The chips were used to measure chips bulk and basic density according to SCAN CN49:92 [18] and SCAN CM-46:92 [19] standard procedures, respectively.
2.2.2. Biomass Productivity. The biomass productivity was calculated using the medium annual increase (MAI) and basic density, by the following equation:

$$
\begin{aligned}
& \text { Biomass productivity (ton/ha/yr) } \\
& \quad=\operatorname{MAI}\left(\mathrm{m}^{3} / \mathrm{ha} / \mathrm{yr}\right) \times \text { basic density }\left(\text { ton } / \mathrm{m}^{3}\right)
\end{aligned}
$$

2.2.3. Samples Preparation for Morphological Analysis. About 200 grams of each biomass sample was sliced into toothpick type material and macerated using a solution of nitric and acetic acid in order to prepare individual fibers for morphological analyses. To make the maceration, a solution of five parts of acetic acid and one part of nitric acid were mixed, added to the biomass material until they were completely immersed and then maintained for 6 hours at $100^{\circ} \mathrm{C}$ under a hood. The reaction was stopped by washing the material, which was dispersed in distilled water. Then, the material was gently mixed in a magnetic stirrer (slowly and steadily) for $60 \mathrm{~min}$, so that all the fiber bundles were separated. Morphological characterization of fibers, vessels, and fines was carried out on a pulp suspension passing through a specific cell illuminated by a laser beam and connected to a high-resolution camera (CCD). This analysis allowed reliable statistical measurement of thousands of fibers, vessels, and fines to determine the main morphological and dimensional characteristics of the pulp components.

2.2.4. Samples Preparation for Chemical Analysis. For the chemical analyses, about $1 \mathrm{~kg}$ of each biomass was sampled and ground in a Wiley type mill to produce sawdust of variable size. This sawdust was screened according to Tappi Standard T257-cml2 [20]. The sawdust that passed the 40mesh screen and was retained in the 60-mesh screen was selected for the chemical analyses. The sawdust was air dried and conditioned in a temperature and humidity controlled room $\left(23 \pm 1^{\circ} \mathrm{C}, 50 \pm 2 \% \mathrm{RH}\right)$ until an equilibrium moisture was achieved $(\sim 10 \%)$. This sawdust (raw sawdust) was used for the chemical analyses. The analyses of ash, silica, chloride, iron, copper, manganese, potassium, calcium, and magnesium were carried out directly on the raw sawdust, according to the Standard Methods for the Examination of Water and Wastewater [21], except for chloride, which was determined according to Tappi T256 cm-07 standard procedure [22]. The biomass extractives contents in acetone, ethanol/toluene $(1: 2)$, and ethanol/toluene $(1: 2) \rightarrow$ ethanol $\rightarrow$ hot water solvent series were also determined in the raw sawdust using the TAPPI T280 pm-99 [23], T204 cm-97 [24], and TAPPI T264 cm-07 [25] standard procedures, respectively. In order to determine biomass main cell wall components, a $200 \mathrm{~g}$ sample of biomass extractives free was prepared using TAPPI T264 cm-07 [16] standard procedure. This extracted sample (extractive free sawdust) was conditioned in a temperature and humidity controlled room $\left(23 \pm 1^{\circ} \mathrm{C}, 50 \pm 2 \% \mathrm{RH}\right)$ until an equilibrium moisture was achieved ( 10\%). The contents of uronic acids, acetyl groups, and sugars (glucans, mannans, galactans, xylans, and arabinans) in the extractive free biomass were determined according to Scott [25], Solar et al. [26], and Wallis et al. [27]. The acid insoluble lignin, 
TABLE 1: Codification of the eucalypt clones and elephant grass species.

\begin{tabular}{|c|c|c|}
\hline & Sample code & Biomass type \\
\hline 1 & U1xU2 & E. urophylla (Flores IP) x E. urophylla (Timor) \\
\hline 2 & $\mathrm{U} 2 \mathrm{xCl}$ & E. urophylla (Timor) $\mathrm{x}$ E. camaldulensis (VM1) \\
\hline 3 & G1xUGL & E. grandis (Coffs Harbour) $\mathrm{x}$ [E. urophylla $(R) \times$ E. globulus $(R)]$ \\
\hline 4 & U1xUGL & E. urophylla $($ Flores $I P) \times[$ E. urophylla $(R) \times$ E. globulus $(R)]$ \\
\hline 5 & $\mathrm{U} 1 \mathrm{xC} 2$ & E. urophylla (Flores IP) x E. camaldulensis (VM2) \\
\hline 6 & $\mathrm{C} 1 \mathrm{xC} 2$ & E. camaldulensis (VM1) x E. camaldulensis (VM1) \\
\hline 7 & DGxUGL1 & {$[$ E. dunnii $(R) \times$ E. grandis $(R)] \times[$ E. urophylla $(R) \times$ E. globulus $(R)]$} \\
\hline 8 & DGxU2 & {$[$ E. dunnii $(R) \times$ E. grandis $(R)] \times$ E. urophylla (Timor) } \\
\hline 9 & ClxUGL & E. camaldulensis $(V M 1) \times[$ E. urophylla $(R) \times$ E.globulus $(R)]$ \\
\hline 10 & G1xGL2 & E. grandis (Coffs Harbour) x E. globulus $(R)$ \\
\hline 11 & $\mathrm{DGxC1}$ & [E. dunnii $(R) \times$ E. grandis $(R)] \times$ E. camaldulensis $(V M 1)$ \\
\hline 12 & $\mathrm{U} 2 \mathrm{xGL} 1$ & E. urophylla (Timor) x E. globulus $(R)$ \\
\hline 13 & DGxGL2 & [E. dunnii $(R) \times$ E. grandis $(R)] \times$ E. globulus $(R)$ \\
\hline 14 & $\mathrm{U} 1 \mathrm{xD} 2$ & E. urophylla (Flores IP) x E. dunnii $(R)$ \\
\hline 15 & U1xG2 & E. urophylla $($ Flores IP $) \times$ E. grandis \\
\hline 16 & IP & E. urophylla $(I P) \times$ E. grandis $(I P)$ commercial clone \\
\hline 17 & VC & E. urophylla $\mathrm{x}$ E. grandis commercial clone \\
\hline 18 & $\mathrm{CC}$ & E. urophylla $\mathrm{x}$ E. grandis commercial clone \\
\hline 19 & EG1 & Pennisetum purpureum \\
\hline 20 & EG2 & Pennisetum americanum \\
\hline
\end{tabular}

acid soluble lignin, and lignin syringyl/guaiacyl (S/G) ratio were determined according to TAPPI T 222 om-97 standard procedure [28], Goldschmid [29], and Lin and Dence [30], respectively.

\section{Discussion and Results}

3.1. Forestry Characteristics. Two very important factors regarding biomass use for pulp production are moisture content and density since they affect harvesting, transportation, and utilization costs. The eucalypt clones analyzed in this study show average moisture and density of 55\% and $502 \mathrm{~kg} / \mathrm{m}^{3}$. These values are considered satisfactory for pulp production [31-34]. The MAI varied in the range of 16$101.6 \mathrm{~m}^{3} / \mathrm{ha} / \mathrm{yr}$. The lowest MAI extreme occurred for the $\mathrm{C} 1 \mathrm{xC} 2$ woody raw material. This may be explained due to the fact that eucalypt hybrid is poorly adapted to Minas Gerais State climate conditions and did not develop satisfactorily. Among the woody raw materials, the highest growth $\left(101.6 \mathrm{~m}^{3} / \mathrm{ha} / \mathrm{yr}\right)$ was obtained with sample DGxU2, which is a triple hybrid of (Eucalyptus dunnii x Eucalyptus grandis) $\mathrm{x}$ Eucalyptus urophylla (Table 2). This productivity is much above the average MAI obtained in commercial plantations in the Brazilian Territory ( 40-60 $\left.\mathrm{m}^{3} / \mathrm{ha} / \mathrm{yr}\right)$ [5].

3.2. Morphological Characteristics. Another important aspect of the raw material for pulp production is its morphological characteristics. The strength and morphology of fibers have a strong influence on the physical properties of paper as well as the wood pulpability $[1,2,35]$. In Table 3 , the morphological characterizations of all the evaluated samples are presented.
It was observed that the fiber content depends on the coarseness; the lower coarseness, the higher fiber content. The fiber coarseness is lower for samples U2xGL1, C1xC2, DGxUGL1, and C1xUGL and higher for samples DGxGL2, IP, and U1xUGL. This fiber coarseness measurement gives indication on the number of fibers required to reach a given basic weight and therefore affects the runnability of the paper machines, for example. The longest mean area-weighted fiber length is obtained for hybrid eucalypt clone $\mathrm{U} 2 \mathrm{xC1}$, followed by samples DGxC1, UG, DGxU2, G1xUGL, U1xUGL, and C1xUGL. The eucalypt clones DGxGL2 and CC have the shortest fiber. The length of the fiber has an influence on the mechanical properties of the final paper [36]. Longer fiber improves mechanical properties of the final paper. Curl index is higher for samples UxGL1, CC, C1xC2, and C1xUGL. This characteristic indicates that the fibers of these samples are less flexible than those of other eucalypt clone fibers. Macrofibrillation index and broken fiber content give information on the state of the fiber before deconstruction pretreatment or pulping. The CC and DGxUGL1 clones presented more broken fiber and the corresponding fiber is more fibrillated than the other clones. The clones DGxGL2, IP, and CC contain a higher amount of broken fiber which can explain the higher amount of fines on these eucalypt clones. For the pulping process, the vessel elements are desirable, since the penetration of cooking liquors is easier. However, for the production of special kinds of paper, such as printing papers, they are considered undesirable, because the vessel on the surface of the paper sheet tends to be pulled thereby causing printing failures; this is known as "vessels picking" [37]. Eucalypt clones DGxC1, U1xU2, U1xD2, U1xG2, G1xUGL, and CC have higher vessels content than the other samples. 
TABLE 2: Forestry and physical characteristics of the eucalypt clones and elephant grass species evaluated.

\begin{tabular}{|c|c|c|c|c|c|}
\hline Sample code & Moisture, \% & $\begin{array}{l}\text { Average annual } \\
\text { increment, } \\
\mathrm{m}^{3} / \mathrm{ha} / \mathrm{yr}^{*}\end{array}$ & $\begin{array}{l}\text { Biomass basic } \\
\text { density, } \mathrm{kg} / \mathrm{m}^{3}\end{array}$ & $\begin{array}{c}\text { Biomass } \\
\text { productivity, } \\
\text { bone dry } \\
\text { ton } / \mathrm{ha} / \mathrm{yr}\end{array}$ & $\begin{array}{c}\text { Chip bulk } \\
\text { density, } \mathrm{kg} / \mathrm{m}^{3}\end{array}$ \\
\hline U1xU2 & 54 & 86.0 & 504 & 43.3 & 209 \\
\hline $\mathrm{U} 2 \mathrm{xC} 1$ & 55 & 54.1 & 547 & 29.6 & 220 \\
\hline G1xUGL & 53 & 46.2 & 500 & 23.1 & 202 \\
\hline U1xUGL & 54 & 46.9 & 496 & 23.3 & 193 \\
\hline $\mathrm{U} 1 \mathrm{xC} 2$ & 53 & 52.9 & 517 & 27.4 & 203 \\
\hline $\mathrm{C} 1 \mathrm{xC} 2$ & 54 & 16.0 & 533 & 8.5 & 207 \\
\hline DGxUGL1 & 55 & 57.7 & 449 & 25.9 & 193 \\
\hline DGxU2 & 56 & 101.6 & 496 & 50.4 & 203 \\
\hline ClxUGL & 53 & 19.9 & 519 & 10.3 & 220 \\
\hline G1xGL2 & 54 & 39.3 & 530 & 20.8 & 211 \\
\hline DGxC1 & 53 & 72.6 & 500 & 36.3 & 213 \\
\hline U2xGL1 & 52 & 40.1 & 506 & 20.3 & 208 \\
\hline DGxGL2 & 55 & 28.5 & 489 & 13.9 & 197 \\
\hline U1xD2 & 54 & 42.6 & 441 & 18.8 & 178 \\
\hline U1xG2 & 56 & 63.4 & 518 & 32.8 & 228 \\
\hline IP & 55 & 80.9 & 480 & 38.8 & 183 \\
\hline VC & 54 & 80.3 & 473 & 38.0 & 179 \\
\hline $\mathrm{CC}$ & 55 & 40.2 & 472 & 19.0 & 183 \\
\hline EG1 & 73 & 148.1 & 216 & 32.0 & 54 \\
\hline EG2 & 75 & 140.0 & 200 & 28.0 & 75 \\
\hline
\end{tabular}

${ }^{*}$ Data provided by the feedstock suppliers.

These vessels' content can be correlated to the growth rate of the tree, as, for example, the higher wood production, the higher vessels content. This means that, for the choice of the best clones to proceed with the study, the length of the fiber and the vessels content are the most important characteristics to help in the choice of the clones that should be used for the cooking process. Hybrid eucalypt clones C1xUGL, U1xUGL, and DGxUGL1 seem interesting because some characteristics, such as vessels content, fiber length, broken fiber, and fines content, are adequate for quality of papers.

Regarding elephant grass samples, a lower fiber content per gram in EG1 and EG2 samples was observed. The width, length, coarseness, fine content, and macrofibrillation index may be considered close to the eucalypt samples. However, the EG1 and EG2 showed a high vessel content. Vessels are recognized to generate problems during printing as explained previously [37]. But in general it is possible to say that the fibers have potential for paper production, since the characteristics desired for paper quality are observed.

3.3. Chemical Characteristics. Table 4 shows the extractive quantity of the eucalypt clones and elephant grass samples extracted with the ethanol/toluene $\rightarrow$ ethanol $\rightarrow$ hot water solvent series, with ethanol/toluene 1:2 only and with acetone. In order to measure the biomass cell wall components, it is relevant to remove all extractives present in the material. The Tappi T204 CM 97 standard procedure [24] (ethanol/toluene $1: 2 \rightarrow$ ethanol $\rightarrow$ hot water) was efficient for removing all polar and apolar extractive fractions. Although this procedure is intended to free the wood from extractives, it serves also to quantify the total amount of extractives present in the biomass, since the main cell wall components (cellulose, hemicelluloses, and lignin) are not soluble in any of the solvents comprising the series. Extraction with ethanol/toluene only extracts substances as waxes, fats, resins, phytosterols, and nonvolatile hydrocarbons. Extraction in acetone [23] serves to quantify those extractives that are more relevant to the pulping operation and pitch formation in the pulp. The acetone extractable content of wood is a measure of such substances as fatty acids, resin acids, sterols, waxes, and nonvolatile hydrocarbons. Because acetone is both more polar and water-miscible than dichloromethane or benzene-ethanol, the quantity of acetone extractable material, especially in wood, may be higher than that found with the other solvents. This procedure will not give the same results as ethanol-toluene or dichloromethane extractions. In their work, Barbosa et al. [38] showed that acetone is the best solvent for the evaluation of the wood lipophilic extract content.

Biomass extractives are quite troublesome since they cause many difficulties in operating the industrial facilities, causing unexpected lost time in the operation for cleaning of equipment and instruments due to their stickiness and 


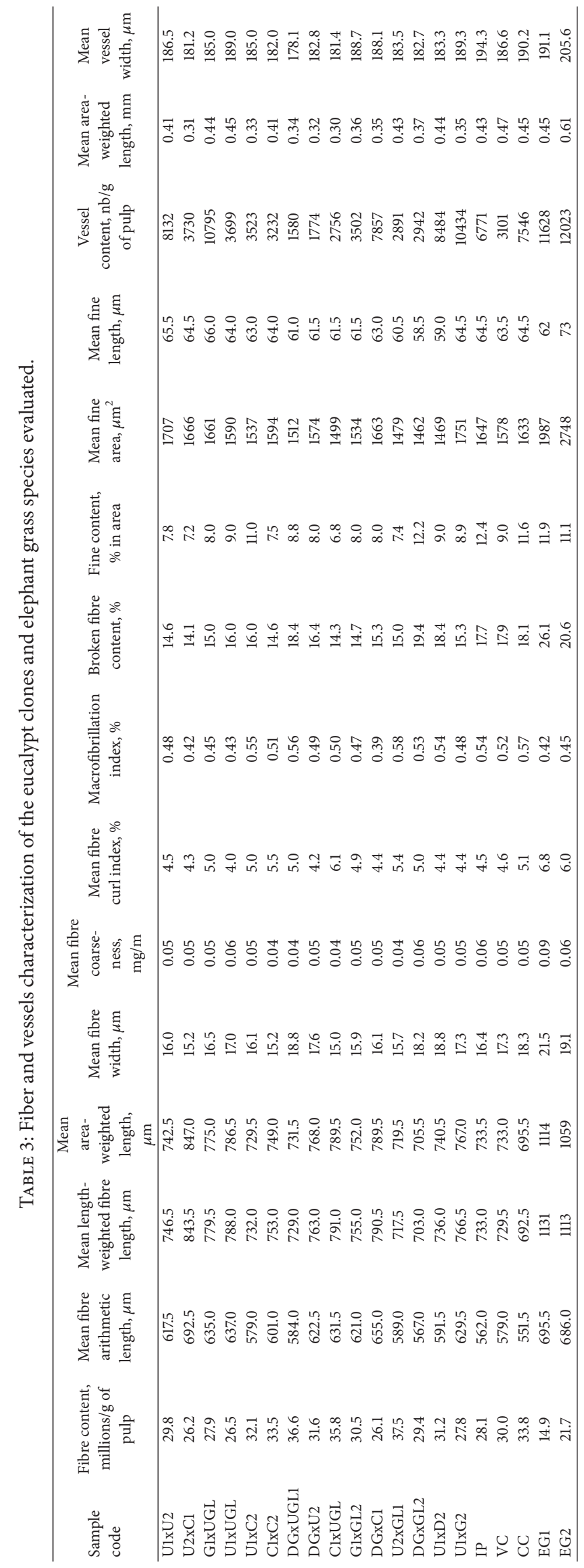


TABLE 4: Extractive content of the eucalypt clones and elephant grass species evaluated.

\begin{tabular}{lccc}
\hline Sample code & $\begin{array}{c}\text { Acetone } \\
\text { extractives, } \%\end{array}$ & $\begin{array}{c}\text { Ethanol/toluene } \\
(1: 2) \\
\text { extractives, } \%\end{array}$ & $\begin{array}{c}\text { Total } \\
\text { extractives, \% }\end{array}$ \\
\hline U1xU2 & 1.7 & 1.9 & 3.6 \\
U2xC1 & 1.1 & 1.4 & 3.4 \\
G1xUGL & 2.5 & 2.5 & 4.9 \\
U1xUGL & 1.9 & 1.3 & 3.6 \\
U1xC2 & 1.2 & 1.2 & 2.8 \\
C1xC2 & 1.2 & 1.3 & 3.0 \\
DGxUGL1 & 1.2 & 2.7 & 2.8 \\
DGxU2 & 1.2 & 2.2 & 2.7 \\
C1xUGL & 0.9 & 1.6 & 2.1 \\
G1xGL2 & 1.2 & 1.9 & 2.8 \\
DGxC1 & 0.9 & 1.2 & 1.9 \\
U2xGL1 & 1.0 & 1.4 & 2.5 \\
DGxGL2 & 1.1 & 1.7 & 1.9 \\
U1xD2 & 2.3 & 2.3 & 3.0 \\
U1xG2 & 2.1 & 1.6 & 2.8 \\
IP & 0.8 & 1.5 & 2.3 \\
VC & 1.6 & 2.6 & 3.7 \\
CC & 1.1 & 2.6 & 3.5 \\
EG1 & 3.9 & 6.8 & 14.8 \\
EG2 & 9.9 & 1.8 & 17.6 \\
\hline
\end{tabular}

tackiness. In addition the deposition of these substances in the pulp may occur, which are called pitch [38], decreasing the pulp value or even its rejection by market. In their study Cruz et al. [39] showed that in pitch composition there are waxes, fats, and long chain alcohols, being the main compounds associated with pitch formation [40].

For the pulp production, among the eucalypt clones acceptable total extractive contents (1.9 to $4.9 \%$ ) were observed for all clones [34, 41]. On the other hand, the EG samples showed a high content of acetone extractives and ethanol/toluene extractives. In addition, pitch formation and pulp dirtiness are much more likely on raw materials containing high content of these extractives. As a consequence, the EG1 and EG2 also presented a high total extractive content (14.8\% and 17.6, resp.) since such materials are likely to result in low yield during cooking process.

The raw material minerals are detrimental for their industrial utilization, since they cause corrosion and deposits on equipment, reduce biomass heating value, and decrease mill throughput. In Table 5 the results of biomass mineral content are presented. In general the amounts of inorganics present in the eucalypt clones were very low and quite acceptable for most applications $[42,43]$. For the eucalypt clones, the total inorganics measured by complete biomass combustion (ash content) varied in the range of $950-2,510 \mathrm{mg} / \mathrm{kg}$ biomass. For the EG1 and EG2, they reached 60,100 , and $37,900 \mathrm{mg} / \mathrm{kg}$, respectively. The very high mineral content in the grass is explained by its fast metabolism at the young age when it needs plenty of minerals to produce the biomass. Another interesting fact about the contents of minerals in biomass is that they tend to decrease with aging due to decreased biomass deposition rate as a function of time [44]. The same trend observed for total inorganics (ash content) is also verified for the individual components such as silica, chloride, calcium, potassium, and magnesium, with the elephant grass samples always presenting higher values than the eucalypt clone samples. Calcium, magnesium, and silica are very undesirable in most industrial processes because of their ability to cause deposits in equipment during evaporation of liquid streams and combustion of solid streams. On the other hand, potassium and chloride are particularly dangerous for their ability to decrease the ash melting point during combustion, thus causing sticky ash problems in recovery boiler systems [45]. In addition, chlorides are highly corrosive and troublesome for most equipment regardless of metallurgy. In regard to transition metals ( $\mathrm{Fe}, \mathrm{Cu}$, and $\mathrm{Mn})$, there were also significant differences among the eucalypt clones and elephant grass materials, again always presenting the same trend, higher content in elephant grass samples.

In Table 6 the biomass chemical composition is presented. There were significant variations among the results of contents of sugars, acetyl group, uronic acids, lignin, and syringyl/guaiacyl ratio of lignin. Among the eucalypt clones, the total lignin contents varied in the range of 27.1 to $31.3 \%$. The maximum value was obtained for the double crossing U1xC2 hybrid and the minimum for the GlxGL2 one. However, these values are considered acceptable for eucalypt clones, but for pulp production a lower lignin content and high $S / G$ ratio are desired due to the increase of the pulpability of the wood [46]. About the carbohydrate content, the eucalypt clones presented values considered satisfactory for eucalypts aiming at pulp production [34].

Regarding elephant grass, the lignin contents for EG1 and EG2 biomass were 18 and 16.5\%, respectively. The low lignin content of the elephant grass samples is advantageous for potentially improving pulping easiness and yield. However, its low lignin S/G ratio and low sugar content work in the opposite direction [46]. The low sugar content of the elephant grass samples reflected their very high extractive and mineral contents.

3.4. Some Relations among Cell Wall Components. In order to determine lignin content, it is necessary to treat biomass with strong acids so that the carbohydrate fraction is hydrolyzed, leaving lignin as a residue. This acid hydrolysis procedure leads to severe lignin condensation and precipitation so that it is easily collected from the solution through simple filtration. Some of the lignin, particularly in hardwoods, seemingly condenses insufficiently in the acid media, becomes soluble, and sieves through the filtration system. This lignin is the so-called acid soluble lignin. Although acid soluble lignin is negligible for softwood biomass, it is quite important for hardwoods. The amount of acid soluble lignin in the woody biomass investigated varied in the range of 4.1-5.6\% of the wood dry weight (Table 5). Although not commonly investigated, the amount of acid soluble lignin seems to be related to the lignin $S / G$ ratio. Lignin containing larger 
TABLE 5: Ash and metal content of the eucalypt clones evaluated.

\begin{tabular}{|c|c|c|c|c|c|c|c|c|}
\hline \multirow{2}{*}{ Sample code } & \multicolumn{8}{|c|}{ Inorganics, $\mathrm{mg} / \mathrm{kg}$ biomass } \\
\hline & Ash & $\mathrm{Cu}$ & $\mathrm{Fe}$ & $\mathrm{Ca}$ & $\mathrm{Mn}$ & $\mathrm{Mg}$ & $\mathrm{K}$ & $\mathrm{Cl}^{-}$ \\
\hline $\mathrm{U1xU2}$ & 950.0 & 0.8 & 15.5 & 307.0 & 9.5 & 81.0 & 194.0 & 260.0 \\
\hline $\mathrm{U} 2 \mathrm{xC} 1$ & 1850.0 & 0.7 & 12.3 & 384.0 & 16.0 & 146.0 & 265.0 & 328.0 \\
\hline G1xUGL & 1950.0 & 0.5 & 13.1 & 452.0 & 14.0 & 112.0 & 188.0 & 629.0 \\
\hline U1xUGL & 1200.0 & 1.2 & 14.6 & 394.0 & 9.8 & 148.0 & 185.0 & 454.0 \\
\hline $\mathrm{U} 1 \mathrm{xC} 2$ & 1250.0 & 0.7 & 10.3 & 328.0 & 9.7 & 144.0 & 340.0 & 594.0 \\
\hline $\mathrm{C} 1 \mathrm{xC} 2$ & 2510.0 & 1.1 & 8.2 & 518.0 & 19.8 & 156.0 & 404.0 & 413.0 \\
\hline DGxUGL1 & 1950.0 & 0.8 & 18.2 & 532.0 & 16.3 & 118.0 & 358.0 & 500.0 \\
\hline DGxU2 & 2280.0 & 1.2 & 13.5 & 531.0 & 13.2 & 123.0 & 218.0 & 427.0 \\
\hline C1xUGL & 2160.0 & 0.6 & 10.6 & 627.0 & 23.6 & 166.0 & 435.0 & 523.0 \\
\hline G1xGL2 & 1790.0 & 0.6 & 19.5 & 525.0 & 18.9 & 129.0 & 450.0 & 446.0 \\
\hline DGxC1 & 1400.0 & 0.9 & 10.6 & 263.0 & 11.2 & 128.0 & 252.0 & 701.0 \\
\hline U2xGL1 & 1800.0 & 0.7 & 13.5 & 475.0 & 14.3 & 136.0 & 152.0 & 519.0 \\
\hline DGxGL2 & 1750.0 & 1.0 & 11.3 & 462.0 & 15.0 & 123.0 & 202.0 & 600.0 \\
\hline $\mathrm{U} 1 \mathrm{xD} 2$ & 1400.0 & 0.8 & 14.8 & 264.0 & 10.9 & 115.0 & 222.0 & 689.0 \\
\hline U1xG2 & 1850.0 & 1.1 & 20.4 & 296.0 & 11.2 & 92.0 & 384.0 & 477.0 \\
\hline IP & 1550.0 & 1.1 & 9.3 & 378.0 & 18.2 & 104.0 & 369.0 & 434.0 \\
\hline $\mathrm{VC}$ & 1800.0 & 1.4 & 9.9 & 491.0 & 2.2 & 123.0 & 469.0 & 488.0 \\
\hline $\mathrm{CC}$ & 1700.0 & 1.2 & 8.5 & 356.0 & 13.9 & 183.0 & 370.0 & 399.0 \\
\hline EG1 & 60100.0 & 8.8 & 11.2 & 423 & 11.1 & 490.0 & 21194 & 15167.0 \\
\hline EG2 & 37900.0 & 3.8 & 67.5 & 352 & 56.5 & 1201.0 & 16055 & 2335.0 \\
\hline
\end{tabular}

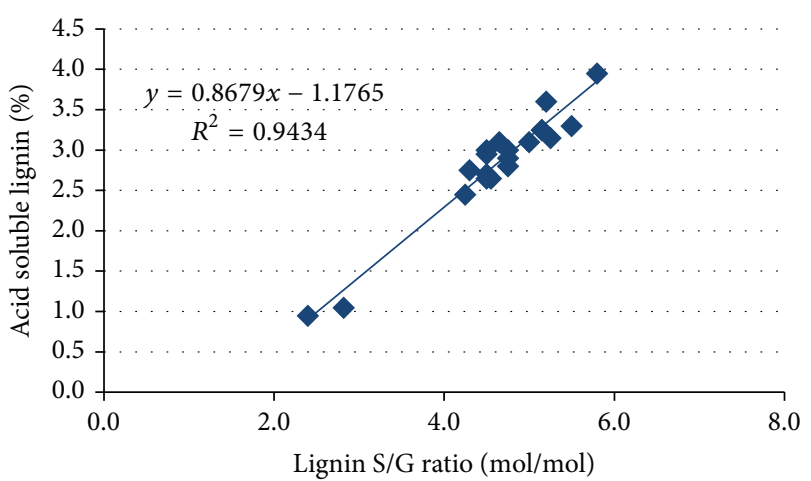

FIGURE 1: Correlation between biomass acid soluble lignin and lignin $\mathrm{S} / \mathrm{G}$ ratio.

amounts of syringyl monomers will condense less during the strong acid hydrolysis treatment, since the $\mathrm{C} 5$ position in the aromatic ring is blocked in the syringyl units. These blocked C5 positions prevent C5 condensation. Therefore, lignin containing high $\mathrm{S} / \mathrm{G}$ ratio, that is, high number of syringyl units, will condense less during the acid hydrolysis procedure and produce more soluble lignin in the filtrates. Figure 1 shows that there is very good correlation between lignin $S / G$ ratio and acid soluble lignin content for the various woody and nonwoody biomass, in agreement with the proposed theory.

3.5. Raw Material Selection. Based on all the analyses, the best five eucalypt clones and one elephant grass selected for the pulp production were
(1) a double crossing hybrid of Eucalyptus urophylla $\mathrm{x}$ Eucalyptus urophylla (U1xU2), that was selected on the basis of its very high annual growth $\left(83 \mathrm{~m}^{3} / \mathrm{ha} / \mathrm{yr}\right)$, high wood density, excellent morphological traits, very high forest yield ( 43 ton/ha/yr), and low xylan and uronic acid contents;

(2) a triple crossing hybrid of Eucalyptus grandis $\mathrm{x}$ (Eucalyptus urophylla x Eucalyptus globulus) (GlxUGL), which presented a high xylan content and possessed Eucalyptus globulus in its genotype, which is of interest for high S/G ratio, although it is quite challenging for its high content of extractives (4.9\%);

(3) a triple crossing of (Eucalyptus dunnii x Eucalyptus grandis) x Eucalyptus urophylla (DGxU2), that was selected due to its highest annual growth $\left(101 \mathrm{~m}^{3} / \mathrm{ha} / \mathrm{yr}\right)$ among all eucalypts evaluated, good density, outstanding morphological traits, and the highest forest yield ( $\sim 50$ ton/ha/yr);

(4) a commercial elite clone (IP) that was obtained from a large Brazilian forest company, which is a double crossing of Eucalyptus urophylla x Eucalyptus grandis, for its excellent forest productivity (38.5 ton/ha/yr), good density, the highest cellulose content, and lowest lignin content among all and also for being a very good reference since it is commercially planted by a large pulp company in Brazil;

(5) regarding the elephant grass, the EG1 (Pennisetum purpureum) was selected; it presented the highest productivity ( $32 \mathrm{ton} / \mathrm{ha} / \mathrm{yr})$ and density $\left(216 \mathrm{~kg} / \mathrm{m}^{3}\right)$ at harvesting age (mature material), highest glucan content, and lowest ash and uronic acid contents among the grasses evaluated. 


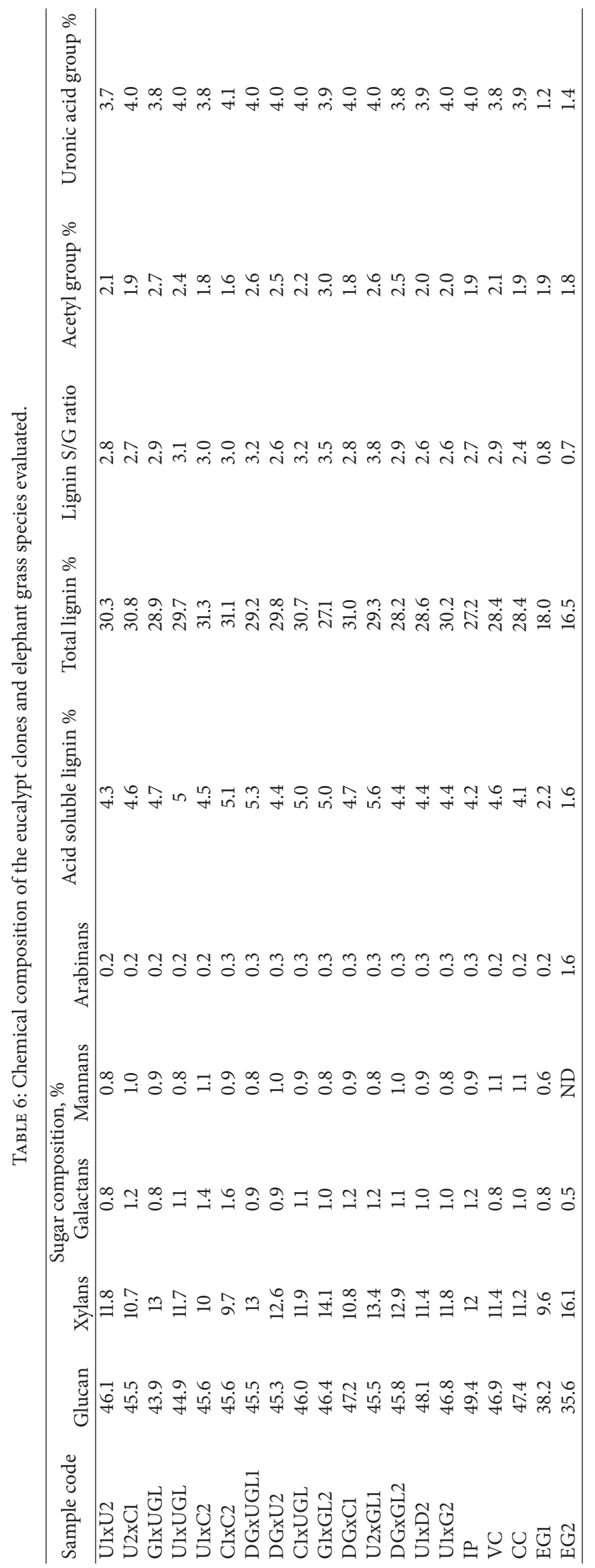




\section{Conclusions}

The results of this study indicate the high technological quality of Eucalyptus clones evaluated and indicate that they can be used for pulp production since they have the suitable characteristics. In general, the eucalypt clones are less moist and denser and contain fewer minerals and extraneous materials than the elephant grass species, which make them more attractive for utilization in deconstruction studies aiming at production of bioproducts.

\section{Conflict of Interests}

The authors declare that there is no conflict of interests regarding the publication of this paper.

\section{Acknowledgments}

Funding provided by the European Community's Seventh Framework Programme FP7/2007-2013 under Grant agreement no. KBBE-2009-3-244362 LignoDeco from the Minas Gerais State Research Foundation (FAPEMIG) and from the Brazilian National Council for Science and Technology Development (CNPq) is greatly appreciated.

\section{References}

[1] C. Foelkel, "As fibras dos eucaliptos e as qualidades requeridas na celulose kraft para a fabricação de papel," in Eucalyptus Online Book e Newsletter, p. 48, 2007, http://www.eucalyptus .com.br/capitulos/PT03_fibras.pdf.

[2] A. Mokfienski, J. L. Colodette, J. L. Gomide, and A. M. M. Ladeira Carvalho, "Relative importance of wood density and carbohydrate content on pulping yield and product quality," Ciência Florestal, vol. 18, no. 3, pp. 401-413, 2008.

[3] T. F. Assis, "Breeding for productivity and quality of short cellulose fiber," in Workshop sobre Melhoramento de Espécies Florestais e Palmáceas no Brasil, pp. 193-214, Embrapa Florestas, 2001.

[4] O. Bison, Improvement of Eucalyptus in order to obtain clones for the pulp industry [Doutorado em Genética e Melhoramento de Plantas], Universidade Federal de Lavras, Lavras, Brazil, 2004.

[5] Bracelpa, Brazilian Pulp and Paper Association, http://www bracelpa.org.br/.

[6] H. Vilela, N. Rodriguez, and E. Dias Teixeira, "Produções de forragem de um híbrido hexaplóide (Pennisetum glaucum X Pennisetum purpureum) e seu valor nutritivo," in Anais da XXXIV Reunião da SBZ, Juiz de Fora, Brazil, Julho 1997.

[7] H. Vilela, F. A. Barbosa, N. Rodriguez, E. Benedetti, and A. C. Nogueira, "Produção e composição química do capim elefante Paraíso submetida a três alturas de corte," in Anais da 39th Reunião Anual da Sociedade Brasileira de Zootecnia, URPE, Recife State of Pernambuco, Brazil, Julho 2002.

[8] H. Vilela, D. Vilela, F. A. Barbosa, and E. Benedetti, "Irrigação do capim elefante Paraíso," in Anais da XXXIX Reunito Anual da Sociedade Brasileira de Zootecnia, URPE-Recife/PE, CD, July 2002.

[9] H. Vilela, D. Vilela, F. A. Barbosa, and E. Benedetti, Quantidade de água suplementar para o capim elefante Paraíso, Veterinária Notícias, 2003.
[10] H. Vilela, D. Vilela, F. A. Barbosa, and E. Benedetti, Análise de Crescimento do capim Elefante Paraíso, Veterinária Notícias, 2003.

[11] V. T. Paulino, T. L. de Lucenas, and R. A. Possenti, Capim elefante cv. Paraíso (Pennisetum hybridum): produção de matéria seca, composição química e biológica em diferentes alturas de corte, 2007, http://www.iz.sp.gov.br/artigos.php?ano=2007.

[12] V. N. G. Mazzarella, Jornada Madeira Energética-Capim Elefante com Fonte de Energia no Brasil: Realidade Atual e Expectativas, IPT-BNDS, Rio de Janeiro, Brazil, 2007.

[13] D. M. Quesada, R. M. Boddey, V. Massena Reis, and A. S. Urquiag, "Parâmetros Qualitativos de Genótipos de Capim Elefante (Pennisetum purpureum Schum.) estudados para a produção de energia através da Biomassa," CIRCULAR TĖCNICA 8. Seropédica, RJ, Novembro. Queima direta de gramínea. Projeto Integrado de Biomassa-PIB. In: Encontro de Energia no Meio Rural, v. 3, Campinas, 2004.

[14] O. Seye, L. A. B. Cortez, and E. O. Gómez, "Queima direta de gramínea. Projeto Integrado de Biomassa-PIB," in Encontro de Energia no Meio Rural, vol. 3, Campinas, Brazil, 2000.

[15] I. C. Madakadze, T. M. Masamvu, T. J. Radiotis, and D. L. LiSmith, "Evaluation of pulp and paper making characteristics of elephant grass (Pennisetum purpureum Schum) and switch grass (Panicum virgatum L.)," African Journal of Environmental Science and Technology, vol. 4, no. 7, pp. 465-470, 2010.

[16] TAPPI Standard, "Preparation of wood for chemical analysis," TAPPI Standard Methods 2007.T264 cm-07, Technical Association of The Pulp And Paper Industry (TAPPI), Atlanta, Ga, USA, 2000.

[17] Scandinavian Standard, "Size distribution," Tech. Rep. SCANCM 40:94, Scandinavian Pulp, Paper and Board Testing Committee Scan Test Methods, 1993.

[18] SCAN-CM 43:95, "Basic density," Scandinavian Pulp, Paper and Board Testing Committee Scan Test Methods, 1995.

[19] SCAN-CM 46:92, "Bulk density," Scandinavian Pulp, Paper and Board Testing Committee, Scan Test Methods, 1993.

[20] TAPPI, "Sampling and preparing wood for analysis," Technical Association of the Pulp and Paper Industry, TAPPI Standard Methods T257cm-12, TAPPI, Atlanta, Ga, USA, 2012.

[21] APHA, Standard Methods for the Examination of Water and Wastewater, American Public Health Association, Washington, DC, USA, 20th edition, 2000.

[22] Technical Association of the Pulp and Paper Industry (TAPPI), "Water-soluble chlorides in pulp and paper," TAPPI Standard Methods T256 cm-07, Technical Association of the Pulp and Paper Industry (TAPPI), Atlanta, Ga, USA, 2000.

[23] TAPPI, "Acetone extractives of wood and pulp," TAPPI Standard Methods T280 pm-99, Technical Association of The Pulp and Paper Industry (TAPPI), Atlanta, Ga, USA, 2006.

[24] TAPPI, "Solvent extractives of wood and pulp," Technical Association of the Pulp and Paper Industry, TAPPI Standard Methods T204 cm-07, TAPPI, Atlanta, Ga, USA, 2007.

[25] R. W. Scott, "Colorimetric determination of hexuronic acids in plant materials," Analytical Chemistry, vol. 51, no. 7, pp. 936-941, 1979.

[26] R. Solar, F. Kacik, and I. Melcer, "Simple semimicro method for the determination of O-acetyl groups in wood and related materials," Nordic Pulp \& Paper Research Journal, vol. 2, no. 4, pp. 139-141, 1987.

[27] A. F. A. Wallis, R. H. Wearne, and P. J. Wright, "Chemical analysis of polysaccharides in plantation eucalypt woods and pulps," Appita Journal, vol. 49, no. 4, pp. 258-262, 1996. 
[28] Technical Association of the Pulp and Paper Industry (TAPPI), "Acid-insoluble lignin in wood and pulp," TAPPI Standard Methods T222 om-11, Technical Association of the Pulp and Paper Industry (TAPPI), Atlanta, Ga, USA, 2011.

[29] O. Goldschmid, "Ultraviolet spectra," in Lignins: Occurrence, Formation, Structure and Reactions, K. V. Sarkanen and C. H. Ludwig, Eds., pp. 241-266, Wiley-Interscience, New York, NY, USA, 1971.

[30] S. Y. Lin and C. W. Dence, Methods in Lignin Chemistry, Springer, Berlin, Germany, 1992.

[31] F. P. Leite, F. J. B. Gomes, E. Souza, A. M. Rosado, and L. S. Amaral, "Investigation of drying time in the humidity content and on physical and chemical characteristics of wood for the production of pulp," in Proceedings of the 42nd Pulp and Paper International Congress and Exhibition, ABTCP, São Paulo, Brazil, 2010.

[32] T. R. Werh and L. E. G. Barrichelo, "Cozimento Kraft com madeiras de Eucalyptus grandis de diferentes densidades básicas e dimensões de cavacos," Jornal O Papel, vol. 54, no. 5, pp. 33-41, 1993.

[33] F. G. Silva Jr., C. F. Do Valle, and J. C. G. Muner, "Programa de qualidade da madeira da votorantim celulose e papel-vcp," Revista O Papel, vol. 57, no. 1, pp. 35-43, 1996.

[34] J. L. Gomide, J. L. Colodette, R. C. Oliveira, and C. M. Silva, "Technological characterization of the new generation of Eucalyptus clones in Brazil for kraft pulp production," Revista Árvore, vol. 29, no. 1, pp. 129-137, 2005.

[35] R. S. Seth and D. H. Page, "Fiber properties and tearing resistance," Tappi Journal, vol. 71, no. 2, pp. 103-107, 1988.

[36] A. C. Nascimento and J. V. Moreira, "Influence of recycled fiber on the physical and mechanical paper properties," Revista de Engenharia e Tecnologia, vol. 1, no. 1, pp. 63-71, 2009.

[37] N. Lindström and P. Fardim, "Chemistry and surface chemistry of vessels in eucalyptus kraft pulps," O Papel, vol. 73, no. 9, pp. 65-72, 2012.

[38] L. C. A. Barbosa, C. R. A. Maltha, and M. P. Cruz, "Chemical composition of lipophilic and polar extractives of Eucalyptus grandis," Science \& Engineering Journal, vol. 15, no. 2, pp. 13-20, 2005.

[39] M. P. Cruz, L. C. A. Barbosa, C. R. A. MalthaI, J. L. Gomide, and A. F. Milanez, "Chemical characterization of pitch in Eucalyptus pulp and paper industry," Química Nova, vol. 29, no. 3, 2006.

[40] S. Karlsson, B. Holmbom, P. Spetz, A. Mustranta, and J. Buchert, "Reactivity of Trametes laccases with fatty and resin acids," Applied Microbiology and Biotechnology, vol. 55, no. 3, pp. 317320, 2001.

[41] J. L. Gomide, N. H. Fantuzzi, and A. J. Regazzi, "Análise de critérios de qualidade da madeira de eucalipto para produção de celulose Kraft," Revista Árvore, vol. 34, no. 2, 2010.

[42] E. Moreira, Effects of acid leaching of wood chips on the kraft process [M.S. thesis], Federal University of Viçosa, Viçosa, Brazil, 2006.

[43] C. E. B. Foelkel, "Quality of eucalyptus wood to meet the requirements of the pulp and paper market," in Proceedings of the Conferência IUFRO Sobre Silvicultura e Melhoramento de Eucalipto, vol. 1, Anais Salvador: IUFRO, Salvador, Brazil, 1977.

[44] P. H. D. Morais, Effect of age of the wood of eucalyptus in its chemical and pulpability, and bleachability and properties of the pulp [M.S. thesis], Federal University of Viçosa, Viçosa, Brazil, 2008.
[45] R. A. Wessel, H. Tran, N. Mahinpey, and D. Kuhn, "Effect of particle composition on carryover deposition in recovery boilers," in TAPPI Fall Conference \& Trade Fair, 2002.

[46] F. J. B. Gomes, A. D. F. G. Gouvêa, J. L. Colodette et al., "Influence of content and S/G relation of the wood lignín on kraft pulping performance," O Papel, vol. 69, no. 12, pp. 95-105, 2008 . 

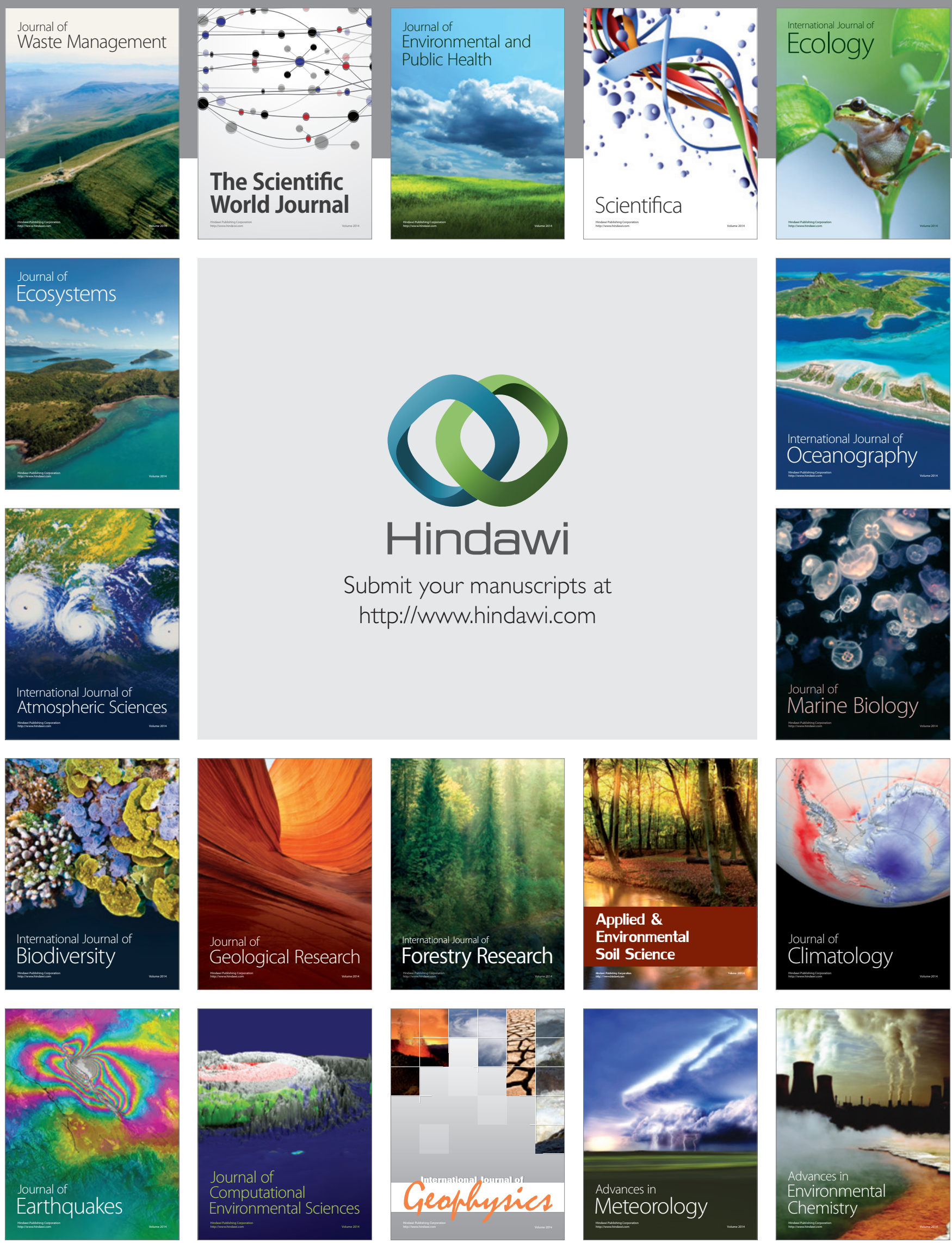